\author{
Dear readers,
}

It is always a great joy for the editorial team to present a new edition and this is indeed the case for Edition 75 of the Revista Contabilidade \& Finanças (Accounting \& Finance Review), which covers the period from September to December 2017. The edition contains diverse themes with the potential to instigate reflection and have an impact on the community.

The Editorial was developed by Salvador Carmona, under the title Accounting History research: scope, topics and research agenda. The author takes a comprehensive look at the topic of accounting history and its research and dissemination mechanisms, supporting this with suggestions for research opportunities.

Besides the editorial, the edition contains nine theoretical-empirical articles and one essay, the first since the approval of the return of this element to the $R C \mho F$ publications profile:

The relevance of accounting information in different periods was addressed in the article IFRS, synchronicity, and financial crisis: the dynamics of accounting information for the Brazilian capital market, whose authors are Bruno Figlioli, Sirlei Lemes, and Fabiano Guasti Lima. The conclusions presented by the authors are different for the various periods.

Challenges with the public policy of measuring assets to set tariffs in the electricity sector: should someone benefit and someone be sacrificed?, written by Maria Elisabeth Moreira Carvalho Andrade and Eliseu Martins, questions the use of the most adequate methodology for price management in the electricity sector, identifying who wins and who loses from the persepective of the concept of fair value.

Leandro Maciel and Rosângela Ballini are the authors of the article titled Value-at-risk modeling and forecasting with range-based volatility models: empirical evidence. The article analyzes volatility models based on variation and GARCH models in a comparative way and concludes that the former provide more precise VaR forecasts than the GARCH models.

The legal forms adopted by microfinance institutions and their performance from a financial perspective, their social performance, and their efficiency in allocating resources, are the subject of the article The relationship between the performance and legal form of microfinance institutions, from Ruan Rodrigo Araújo da Costa. The study concludes with forward-looking suggestions for the entities.

Felipe Fontaine Rezende, Roberto Marcos da Silva Montezano, Fernando Nascimento de Oliveira, and Valdir de Jesus Lameira are the authors of the article titled Predicting financial distress in publicly-traded companies. The authors address a traditional and relevant topic for the business environment, suggesting that financial distress should be included as a step prior to bankruptcy.

On an international level involving 35 countries, would the occurrence of tax avoidance be affected by the convergence of norms? This is the topic of the article titled Effects of IFRS adoption on tax avoidance, written by Renata Nogueira Braga.

The effect of asymmetric information risk on returns of stocks traded on the BM\&FBOVESPA is the article written by Leonardo Siqueira, Hudson Amaral, and Laise Correa. The authors conclude that informational risk works as a complement to the size factor and that its inclusion leads to an improvement in the performance of the models, indicating the possible explanatory power of informational risk in terms of portfolio returns. 
Life tables are key tools for the actuarial area and specific segments present demands of a certain complexity, which in the absence of national tables implies the use of studies from other countries. The article Executive branch federal civil servant mortality by sex and educational level - 1993/2014, written by Kaizo Iwakami Beltrão and Sonoe Sugahara, addresses this topic by presenting a solution for the Brazilian segment.

The article titled Impacts of the regulatory model for market risk capital: application in a special savings company, an insurance company, and a pension fund analyzes the application of the regulatory model, considering the updating of market volatility, by taking into account the practical implications of the new market risk requirement for managing the investments of entities supervised by SUSEP. The authors are Felipe Tumenas Marques and Betty Lilian Chan.

Ariovaldo dos Santos and Paola Londero Richter are the authors of the paper titled ICPC 14: what is missing? The essay addresses the discussion on reclassifying cooperative member quotas from net equity to liabilities. This is a very controversial topic, with relevant consequences for accounting and the financial environment as a whole.

On behalf of all the editors, I wish you an inspiring and productive read.

\section{Fábio Frezatti}

Editor-in-Chief

Departamento de Contabilidade e Atuária

Faculdade de Economia, Administração e Contabilidade

Universidade de São Paulo

Email: frezatti@usp.br 